\title{
Application of a Hybrid Cellular Automaton - Markov (CA-Markov) Model in Land-Use Change Prediction: A Case Study of Saddle Creek Drainage Basin, Florida
}

\author{
Praveen Subedi $^{1, *}$, Kabiraj Subedi ${ }^{2}$, Bina Thapa ${ }^{3}$ \\ ${ }^{1}$ School of Forest Resources and Conservation, University of Florida, Gainesville, FL \\ ${ }^{2}$ Department of Geography, P.N. Campus, Tribhuvan University, Nepal \\ ${ }^{3}$ Department of Earth and Environment, Florida International University, Miami, FL \\ *Corresponding author: praveensubedi@ufl.edu
}

Received May 15, 2013; Revised September 23, 2013; Accepted December 01, 2013

\begin{abstract}
We utilized spatio-temporal data to investigate the applicability of a hybrid (CA- Markov) model in predicting land-use change in Saddle Creek drainage basin in Florida. Agreement statistics (Kappa) between the actual land-use and that predicted by our model showed an acceptable level of prediction accuracy. This demonstrated the validity of the model in land-use change prediction in our study. Our model predicted a notable increase in the urban areas (47.3 \% to 49.4\%) and transportation facilities (3.7\% to $5 \%$ ) from 2006 to 2015. On the contrary, agricultural areas are predicted to decline from $14.4 \%$ to $12.3 \%$ between these periods.
\end{abstract}

Keywords: CA-Markov model, land-use change, prediction, accuracy

Cite This Article: Praveen Subedi, Kabiraj Subedi, and Bina Thapa, “Application of a Hybrid Cellular Automaton - Markov (CA-Markov) Model in Land-Use Change Prediction: A Case Study of Saddle Creek Drainage Basin, Florida.” Applied Ecology and Environmental Sciences 1, no. 6 (2013): 126-132. doi: 10.12691/aees-1-6-5.

\section{Introduction}

Understanding land-use change has been a matter of interest and concern among landscape planners and environmentalist because of the influence land-use change has on the global environment. While changes in land-use are usually of anthropogenic origin, natural factors such as slope, aspect, elevation could also guide these changes. As a result, modeling land-use dynamics is a complex process. The complexity often emanates from the factors likes natural setting, society, economics, culture, politics, and legal aspects influencing the land-use dynamics [1]. Several approaches have been used to model land-use change; mathematical models (linear and static), systems model (stocks and flow), statistical models (regression), cellular models (Cellular Automata (CA) and Markov Chains), evolutionary models (neural networks), agent based models [2,3]. These approaches are often combined together to create a hybrid model.

With recent advances in geographic information systems (GIS), integration of land-use change models into GIS has been possible. Of these models, cellular automata and hybrid models are used widely for land-use change modeling [4,5]. Based on historical spatio-temporal data, here, we try to predict future land-use change using a hybrid CA-Markov model integrated into GIS software. The major objective of this study was to demonstrate the applicability of hybrid CA- Markov models in land-use change prediction. Specifically, we intend to predict landuse change for the year 2015 in a Saddle Creek drainage basin located in Polk County, Florida by using a CAMarkov Model.

\section{Materials and Methods}

\subsection{Study Area}

Saddle creek drainage basin in Polk County located in the Central Florida was chosen as the study area for this project (Figure 1). Saddle creek drainage basin constitutes a major portion of Peace River- Saddle Creek Watershed. The total area of the drainage basin is approximately 253 square kilometers with a population density of 384 persons per sq. $\mathrm{km}$ [6]. Urban area (43\%) was the predominant land-use in this basin followed by agriculture (17\%) and water bodies (16\%) in 1995. Urbanization and agricultural practices have played a major role in dictating the fate of the ecology of this drainage basin. The major reasons behind choosing Saddle Creek drainage basin for land-use change prediction are the growing population, available data sets, and ecologically impaired water bodies [7]. The population growth rate of the watershed between 2000 and 2010 was higher than the statewide growth rate in that period [6] and will continue to increase in the future and so will the infrastructures of development. So, identifying the potential areas that are likely to covert to other land-use classes could help decision makers and 
landscape planner guide their policies to better maintain the ecological integrity of the drainage basin.

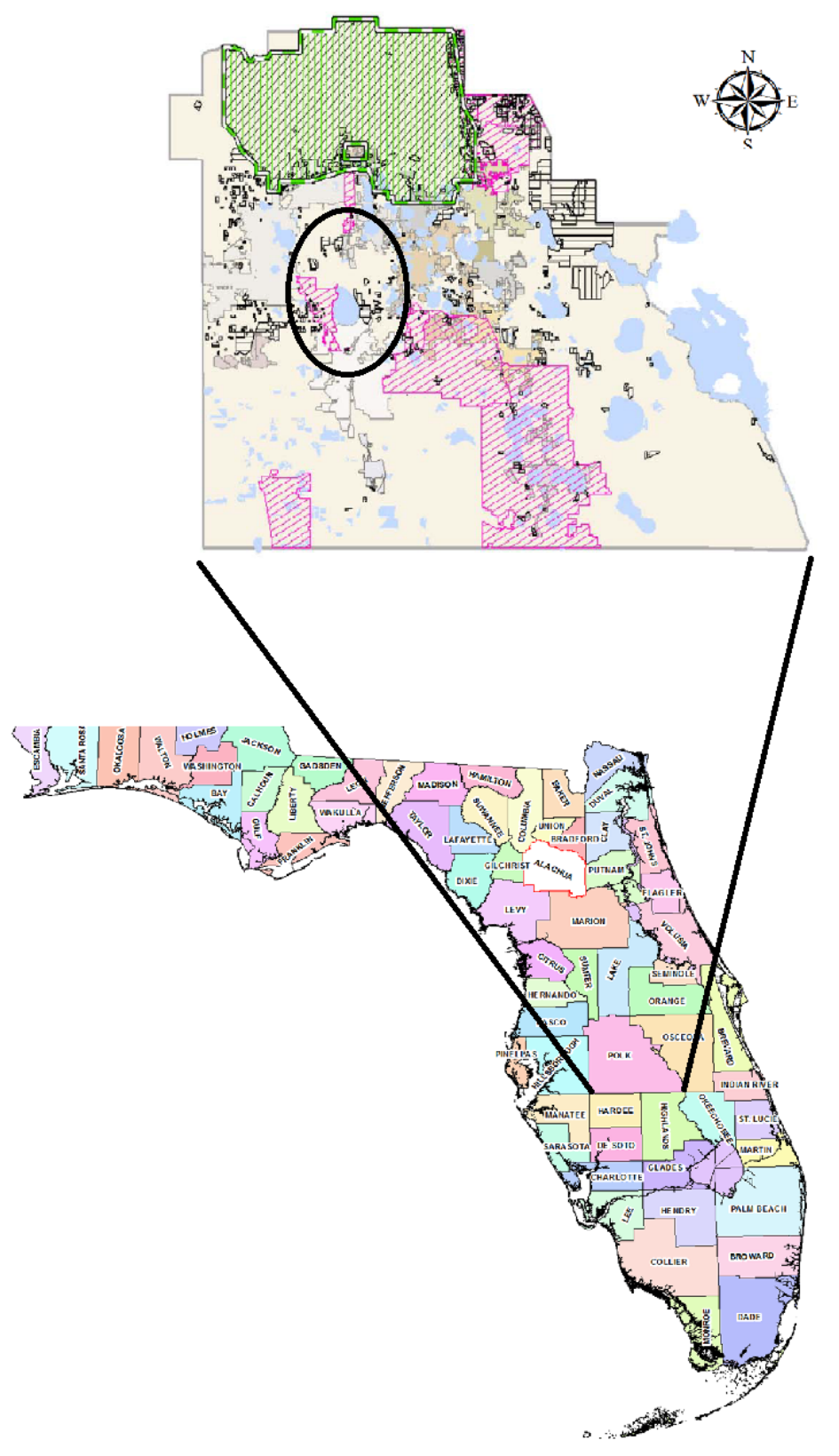

Figure 1. Map of study area in Polk County, FL

\subsection{Data Sources and Processing}

Three land-use land cover vector data sets for Polk County prepared by Southwest Florida Water Management District (SWFWMD) dated 1995, 1999 and 2006 were used for this project. Because we intended to demonstrate the applicability of the CA-Markov model in land use change prediction, the choice of the dates were entirely based on the availability of datasets. These landuse land cover shape files were prepared by South West Florida Water Management District [8,9,10,11]. The landuse land cover classes were categorized using Florida Land Use and Cover Classification System (FLUCCS) [12]. For this study, relevant land-use classes were aggregated into eight major land-use classes; urban and builtup, agricultural areas, rangeland, upland forests, water bodies, wetlands, barren land, and transportation and utilities. ArcGIS 9.2 Desktop [13] was utilized to reclassify land-use land cover shape files into raster images with major land-use classes and a cell resolution of 30m*30m. These land-use maps were then exported into TIFF files for further analysis in IDRISI Andes (v 15.0) [14] for land-use change prediction. In IDRISI Andes, modules like MARKOV, CA-MARKOV, and VALIDATE were used for modeling and projecting the land-use change for the Saddle Creek drainage basin for the year 2015 by using 2006 land-use map as the base map. In order to see how rapidly land-use changes, we set the forecast year to 2015 for this study.

\subsection{Markov Model}

Markov model has been widely used in ecological modeling [15,16]. Markov model takes into account past states to predict how a particular variable changes over 
time. The applicability of Markov model in land-use change modeling is promising because of its ability to quantify not only the states of conversion between landuse types but also the rate of conversion among the landuse types [17]. A homogenous Markov model for predicting land-use change can be represented mathematically as;

$$
L_{(t+1)}=P_{i j} * L_{(t)}
$$

and

$$
P_{i j}=\left[\begin{array}{cccc}
P_{11} & P_{12} & \cdots & P_{1 m} \\
P_{21} & P_{22} & \cdots & P_{2 m} \\
\vdots & \vdots & \vdots & \vdots \\
\vdots & \vdots & \vdots & \vdots \\
P_{m 1} & P_{m 2} & \cdots & P_{m m}
\end{array}\right]
$$

where, $\mathrm{L}_{(\mathrm{t}+1)}$ and $\mathrm{L}_{(\mathrm{t})}$ are the land-use status at time $\mathrm{t}+1$ and $\mathrm{t}$ respectively. $\left(0 \leq P_{i j}<1\right.$ and $\sum_{j=1}^{m} P_{i j}=1$, $(i, j=1,2, \cdots, m))$ is the transition probability matrix in a state.

\subsection{CA-Markov Model}

CA-Markov model combines cellular automata, Markov chain, multi-criteria, and multi-objective land allocation to predict land cover change over time [17]. It adds into Markov model not only spatial contiguity but also the probable spatial transitions occurring in a particular area over a time. MARKOV and CA_MARKOV modules in IDRISI Andes were used to create transition probability and transition area matrix. A transition probability matrix is obtained by cross tabulation of two images of different time and it determines the probability of a pixel in a land-use class to change into another class during that time.

A transition area matrix, on the other hand, contains the number of pixels that are expected to change to a land-use class from another class during a time period. Land-use map dated 1995 and 2006 were used to create transition probability matrix in order to project land use for the year 2015 (Table 1). For creation of transition probability matrix, MARKOV module in IDRISI Andes was used and the proportional error was set to be $15 \%$ [18].

Table 1. Transition probability matrix calculated using land-use maps 1995 and 2006

\begin{tabular}{lllllllll}
\hline Land-use classes & $\begin{array}{l}\text { Urban } \\
\text { builtup }\end{array}$ & $\begin{array}{l}\text { and } \\
\text { agricultural }\end{array}$ & Rangeland & $\begin{array}{l}\text { Upland } \\
\text { forest }\end{array}$ & $\begin{array}{l}\text { Water } \\
\text { bodies }\end{array}$ & Wetlands & $\begin{array}{l}\text { Barren } \\
\text { land }\end{array}$ & $\begin{array}{l}\text { Transportation } \\
\text { and utilities }\end{array}$ \\
\hline Urban and builtup & 0.9465 & 0.0183 & 0.0005 & 0.0045 & 0.0047 & 0.003 & 0.0009 & 0.0216 \\
Agricultural areas & 0.1764 & 0.7831 & 0 & 0 & 0.0049 & 0.0177 & 0.0003 & 0.0177 \\
Rangeland & 0.1592 & 0.0259 & 0.7453 & 0.0238 & 0 & 0.0458 & 0 & 0 \\
Upland forest & 0.1218 & 0.0301 & 0.0058 & 0.7995 & 0.004 & 0.0153 & 0 & 0.0235 \\
Water bodies & 0.0013 & 0.0002 & 0 & 0 & 0.974 & 0.0236 & 0 & 0.0009 \\
Wetlands & 0.109 & 0.0035 & 0.011 & 0.0156 & 0.0374 & 0.8188 & 0 & 0.0047 \\
$\begin{array}{l}\text { Barren land } \\
\begin{array}{l}\text { Transportation } \\
\text { utilities }\end{array}\end{array}$ & 0.8728 & 0 & 0 & 0 & 0.0034 & 0 & 0.1238 & 0 \\
\hline
\end{tabular}

\subsection{Suitability Maps for Land-Use Change Projection:}

Suitability maps were prepared by setting transition rules from a land-use state to another state. While socioeconomic factors are prime drivers of land-use change, only physical factors were considered in this project. The physical proximity to an existing land-use class is thought to be a driver of change into a particular land-use class in the future. Also some restrictions such as developing an urban area into agricultural area were also taken into consideration for preparation of land-use suitability maps. Transition rules were prepared for each land-use class and suitability maps were prepared. The pixel values in suitability maps ranged from 0 to 255, 0 representing unsuitable and 255 representing highly suitable. Figure 2 represents the suitability maps for each land-use classes.

Generally areas near an existing land-use class are likely to change into that class compared to areas that are far from that class. So, inverse J-shaped monotonic decrease function was used to determine the relative suitability of an existing land-use to change into that same land-use. Also, restrictions for agricultural area, barren land, rangeland, upland forests were the urban and built up areas, water bodies, and transportation and utilities.
The CA_MARKOV module in IDRISI uses a hybrid Markov- CA model that iterates the land-use allocation until the areas that are predicted by Markov model are identified. Also the number of iteration is dependent upon the number of years a projection is made. In this project, the number of iterations performed was 9 because the land-use map of 2006 was taken as a base map for projecting the land-use in 2015. A contiguity filter of a kernel size of $5 * 5$ pixels that accounts the neighborhood pixels was used to create spatially explicit contiguous weighing factors so that the pixels that are far from the existing land-use class have lower suitability than the pixels that are near. In this project, the filter used for analysis was;

$$
\begin{array}{lllll}
0 & 0 & 1 & 0 & 0 \\
0 & 1 & 1 & 1 & 0 \\
1 & 1 & 1 & 1 & 1 \\
0 & 1 & 1 & 1 & 0 \\
0 & 0 & 1 & 0 & 0
\end{array}
$$

The weighted suitability maps are then run through a multi-objective land allocation process to allocate the predicted land-use change and resolve the conflicts on allocation by allocating a cell to a particular land-use class for which its weighted suitability is highest [19]. 

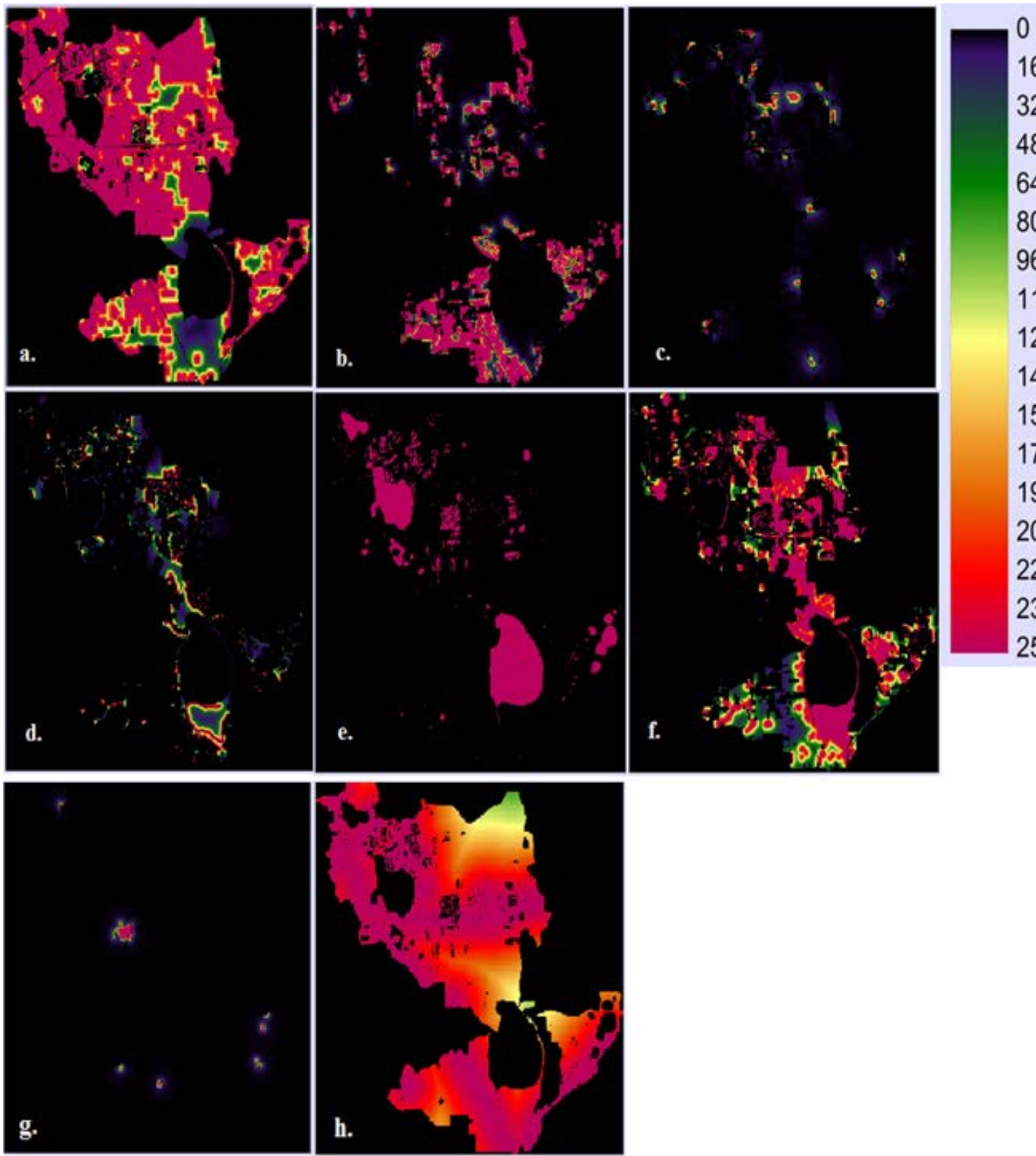

Figure 2. Suitability maps for a. urban and built up b. agricultural area c. rangeland d. upland forest e. water bodies f. wetland g. barren land h. transport and utilities. The values represent the likelihood of a pixel being changed into a land-use class.

\begin{tabular}{llll} 
& Table 2. Projected land-use in 2015 in Saddle Creek drainage basin and percentage total area in 2006 \\
\hline Land-use Classes & Projected Area (Sq. km) in 2015 & Percent total area (in 2015) & Percent total area (in 2006) \\
\hline Urban and builtup & 124.93 & 49.38 & 47.21 \\
Agricultural areas & 31.20 & 12.33 & 14.38 \\
Rangeland & 1.58 & 0.62 & 0.60 \\
Upland forest & 11.26 & 4.45 & 5.05 \\
Water bodies & 43.61 & 17.24 & 16.91 \\
Wetlands & 27.38 & 10.82 & 12.06 \\
Barren land & 0.21 & 0.08 & 0.08 \\
Transportation and utilities & 12.83 & 5.07 & 3.71 \\
\hline
\end{tabular}

\section{Results and Discussion}

The projected land-use map for the year 2015 is provided in Figure 3. Land-use classes like urban and built up and transportation and utilities will have a notable increase in area in 2015 compared to 2006 land-use.
Agricultural areas, upland forest and wetland areas will have a notable decrease in area in 2015 (Table 2). In 2015, urban areas are projected to cover $49.3 \%$ of the total area of Saddle Creek drainage basin followed by water bodies $(17.2 \%)$, wetlands $(10.8 \%)$, transportation and utilities (5\%), upland forest (4.4\%), rangeland (0.6\%), and barren land $(0.08 \%)$. 


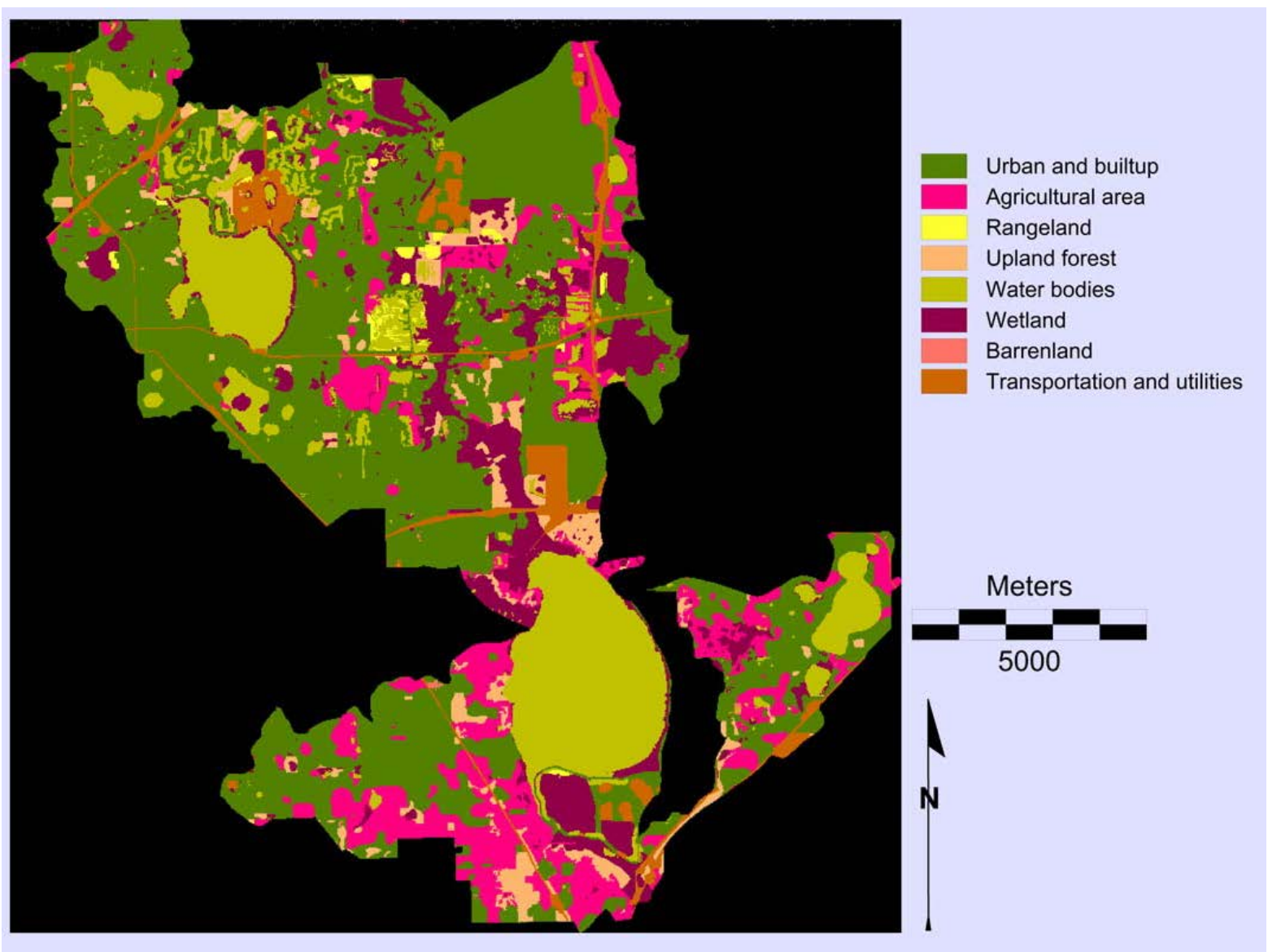

Figure 3. Projected land-use map of Saddle Creek drainage basin, Florida for 2015

Decline in the natural vegetation of Florida has been observed over the past few decades. For instance, Kautz et al. (2007) [20] documented a decline rate as high as 94 thousand hectares per year from mid 1980s to early 2000. In addition, reduction in agricultural land have been observed in florida with an annual reduction rate as high as almost 25 thousand hectares [20]. With urban sprawling, coverstion of forest areas and agricultural land to urban areas was expected in this drainage basin.

While estimates of the rate of land-use conversions via remote sensing techniques are influenced by spatiotemporal resolution, the unforseeable nature of land-use change dynamics obscure the accuracy of change prediction. Nevertheless, population growth and migration into urban areas will lead to relatively higher land-use conversion to urban and residential areas. Other factors such as family size [21] and income [22] also have predictable influence the dynamics of land-use change. For example, families with low income will likely reside in the outskirts of urban area or near urban-agricultural fringe and thereby facilitate land conversion. Because CAMarkov model allows to include the effects of these factors on land-use change, past studies have used successfully predicted land-use change using hybrid models like in this study $[17,23]$.

Table 3.Validation of projected 1999 land-use map with actual 1999 land-use map

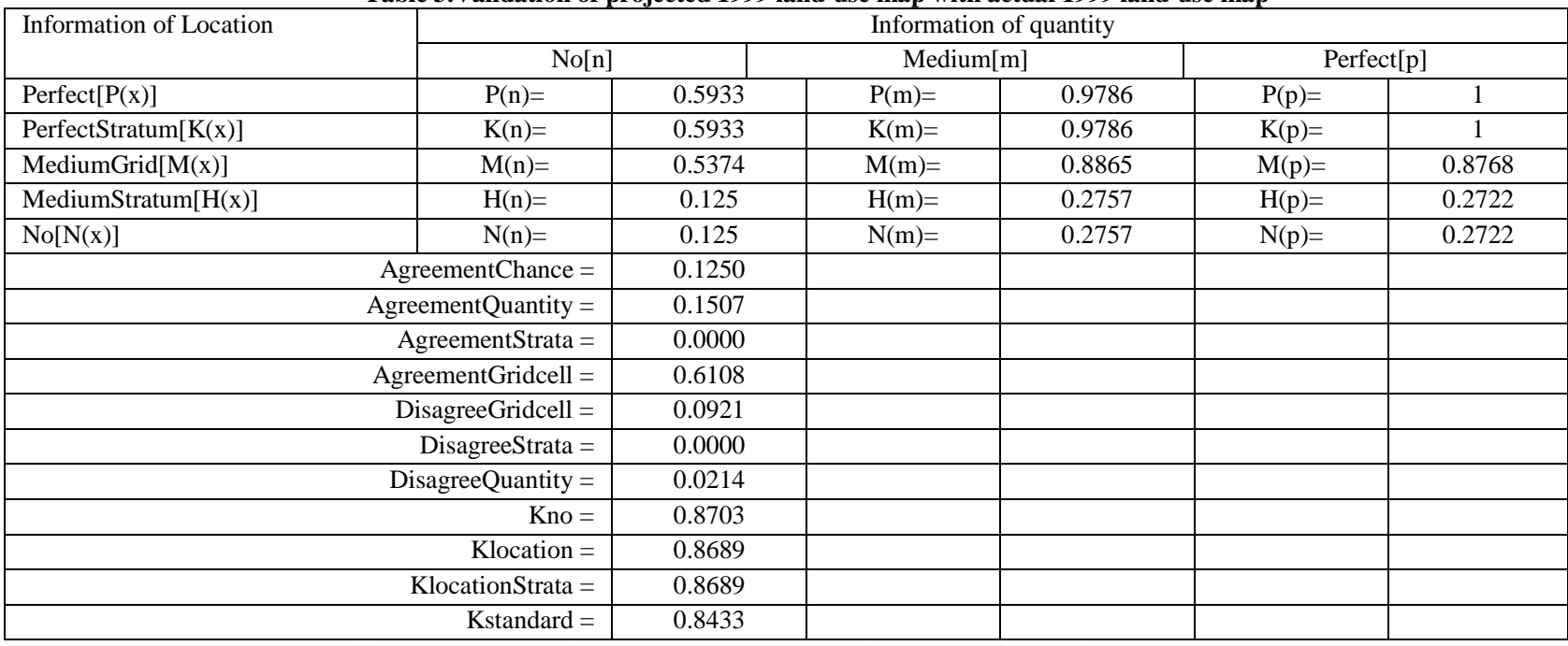

Note: The table shows the classification agreement/disagreement according to ability to specify quantity and location accurately. 

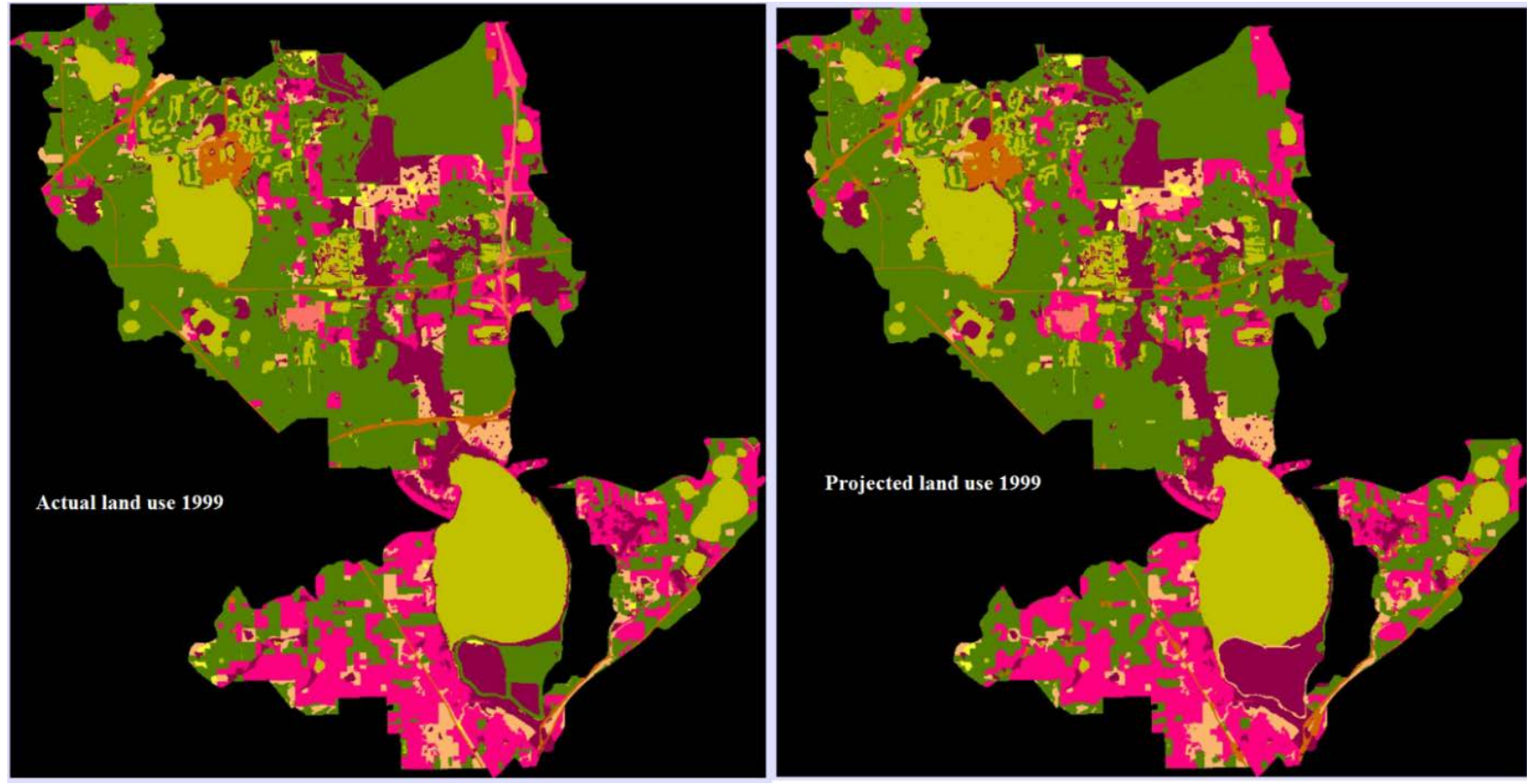

Figure 4. Actual and Projected land-use in Saddle Creek drainage basin for 1999

\section{Evaluation of the Model}

In order to evaluate the model, 1995 land-use map was taken as the base map and all the suitability maps and transition area matrix developed for projecting 2015 landuse map was utilized as inputs in the CA_MARKOV module. CA iterations were done for 4 times to project the land-use for 1999. A comparison of similarity between the projected 1999 map and actual 1999 land-use map was made to evaluate the suitability of the model used for this project to successfully predict land-use change (Figure 4).

This was done using a VALIDATE module in IDRISI Andes. Kappa statistics (K) for similarity was assessed to see the similarity in classification between the actual and projected land-use maps of 1999 [24]. Since all K statistics $\left(\mathrm{K}_{\text {standard }}=84.33 \%, \mathrm{~K}_{\mathrm{no}}=87.03 \%\right.$, and $\mathrm{K}_{\text {locality }}=$ 86.89\%) were well above $80 \%$ [25], the CA-Markov model utilized for this land-use change projection in Saddle Creek drainage basin was considered valid (Table 3).

\section{Limitations and Conclusions}

Because the main objective of this study was to demonstrate the use of CA-Markov model in land-use change prediction, direct use of the results from this study in urban planning or policy formulation should be made with caution. While CA-Markov model adds a spatial component to the traditional Markovian model, there are several limitations to this model. Since this model does not take into account the socio-economic factors such as the population growth, owner's willingness to convert a land, and change in the land-use policies during the period of simulation, incorporation of these factors into the model while creating suitability maps would likely represent more accurate land-use change. Besides proximity to existing land-use, factors such as slope, aspect, elevation, and other limiting factors also constrain land-use change. So, identification and inclusion of factors that are likely to affect a transition of a land-use class to another class in to the CA-Markov model would greatly improve the predictive power of the model. Nevertheless, inclusion of spatio-temporal land-use change dynamics in hybrid models such as CA-Markov, prove to be a valuable tool for better land use change prediction.

\section{Acknowledgements}

This study is a part of a project paper submitted to the School of Forest Resources and Conservation, University of Florida, as a requirement for FOR6156, 2012. We would like to acknowledge Dr. Wendell Cropper for his valuable suggestion regarding the choice of land-use change model at earlier stages this study. We also would like to extend our thanks to PradeepSubedi for his assistance with GIS analyses.

\section{References}

[1] Lambin, E.F., "Modelling and monitoring land-cover change processes in tropical regions”, Progress in Physical Geography, 21, 375-383. 1997.

[2] Parker, D.C., Manson, S.M., Janssen, M.A., Hoffmann, M.J., and Deadman, P., "Multi agent systems for the simulation of land-use and land-cover change: a review”, Annals of the Association of American Geographers, 93, 314-337. 2003.

[3] Agarwal, C., Green, G. M., Grove, J. M., Evans, T. P., and Schweik, C. M., "A review and assessment of land-use change models: dynamics of space, time, and human choice", Gen. Tech. Rep. NE-297, U.S. Department of Agriculture, Forest Service, Northeastern Research Station. Newtown Square, PA. 2002. p 61.

[4] Wood, E.C., Lewis, J.E., Tappan, G.G., and Lietzow, R.W., "The development of a land cover change model for Southern Senegal”, 1997. [Online] Available online at:

http://www.ncgia.ucsb.edu/conf/landuse97/papers/wood_eric/pecd oc.html [Accessed Mar 3, 2012].

[5] Breuer, J.A., Huisman, A., Frede, H.-G., "Monte Carlo assessment of uncertainty in the simulated hydrological response to land use change”, Journal of Environmental Model Assessments, 11, 209218. 2006. 
[6] US Census Bureau, "State and County Quick Facts", 2010 [Online] Available at: http://quickfacts.census.gov/qfd/index.html [Accessed Feb 26, 2012]

[7] Florida Department of Environmental Protection, "Ecosummary, Upper Saddle Creek, Polk County, Peace River Watershed”, 1998. [Online] Available at:

http://www.polk.wateratlas.usf.edu/upload/documents/Upper_Sad dle_Creek_EcoSummary_Polk.pdf [Accessed Feb 7, 2012].

[8] Southwest Florida Water Management District, "Land-use land cover of Polk County in 1995”, 1995. [Online] Available at: http://www.swfwmd.state.fl.us/data/gis/layer_library/category/phy sical_dense [Accessed Feb 5, 2012].

[9] Southwest Florida Water Management District, "Land-use land cover of Polk County in 1999”, 1999. [Online] Available at: http://www.swfwmd.state.fl.us/data/gis/layer_library/category/phy sical_dense [Accessed Feb 5, 2012].

[10] Southwest Florida Water Management District, "Land-use land cover of Polk County in 2006”, 2006. [Online]Available at: http://www.swfwmd.state.fl.us/data/gis/layer_library/category/phy sical_dense [Accessed Feb 7, 2012].

[11] Department of Environmental Protection, "Drainage basins, Water Resources (inland), Florida shapefile”, 1999. [Online] Available at: www.dep.state.fl.us [Accessed Feb 5, 2012].

[12] Florida Department of Transportation, Surveying and Mapping Office, "Florida land use, cover and forms classification system handbook", Tallahassee, FL, USA. 1999.

[13] Environmental Systems Research Institute, “ArcGIS Desktop: Release 9.2", Redlands, CA. 2006.

[14] Eastman, J.R., "IDRISI Andes”, Clark University, Worcester, MA. 2006.

[15] Muller, M.R., Middleton, J., “A Markov model of land-use change dynamics in the Niagara region, Ontario, Canada", Landscape Ecology, 9, 151-157. 1994.
[16] Brown, D.G., Pijanowski, B.C., Duh, J.D., "Modeling the relationship between land use and land cover on private lands in the Upper Midwest, USA", Journal of Environmental Management, 59, 247-263. 2000.

[17] Sang, L., Zhang, C., Yang, J., Zhu, D, and Yun, W., "Simulation of land use spatial pattern of towns and villages based on CAMarkov model”, Mathematical and Computer Modelling, 54, 938943. 2011.

[18] Eastmann, J.R., "Idrisi Andes Tutorial", Clark University, Worcester, MA. 2006. p. 284.

[19] Houet, T., Laurence, H.-M., "Modelling and projecting land-use and land-cover changes with a cellular automaton in considering landscape trajectories: an improvement for simulation of plausible future states”, EARSeLeProceedings, 5, 63-76. 2006.

[20] Kautz, R., Stys, B., and Kawula, R., "Florida vegetation 2003 and land use change between 1985-89 and 2003", Florida Scientist, 70(1), 12-23. 2007.

[21] Fujita, M. (1989). Urban Economic Theory.Cambridge University Press, Cambridge.

[22] Hartwick, J. M., Schweitzer, U., and Varaiya, P.,’Comparative statistics of a residential economy with several classes", Journal of Economic Theory 13, 396-413. 1976.

[23] Weng, Q., "Land use change analysis in the Zhujiang Delta of China using satellite remote sensing, GIS and stochastic modelling”, Journal of environmental management, 64(3), 273284. 2002.

[24] Pontius, R.G.Jr., "Quantification error versus location error in comparison of categorical maps", Photogrammetic Engineering \& Remote Sensing, 66, 1011-1016. 2000.

[25] Viera, A. J. and Garrett, J. M., "Understanding interobserver agreement: the kappa statistic”, Family Medicine37(5), 360-363. 2005. 